\title{
Indiscipline among Staff of Ebonyi State Owned Tertiary Educational Institutions
}

\author{
Paul Nwakpa \\ Department of Educational Foundations \\ Faculty of Education, Ebonyi State University \\ Abakaliki, Nigeria \\ Email: bropaulnwaoo [AT] gmail.com
}

\begin{abstract}
The study investigated the nature, causes, effects of indiscipline among staff of tertiary educational institutions owned by Ebonyi State government and strategies to be adopted in order to curb indiscipline among the staff. The study was guided by four research questions and three null hypotheses. The population of the study was 500 respondents. Questionnaire was used to collect data from the respondents. The questionnaire was validated by five experts from the department of Science Education of Enugu State University of Science and Technology. The reliability index of the instrument was 0.84 obtained through test-retest procedure via pearson's product moment correlation. Mean scores were used to answer the research questions while t-test was used to analyze the hypotheses at 0.05 alpha level of significance. The results of the study revealed the nature, causes, effects and strategies to be adopted to curb indiscipline among staff of tertiary educational institutions owned by Ebonyi State government. Based on the findings, some recommendations were made to include, the adoption of the recommended and accepted strategies to curb indiscipline among staff of Ebonyi State owned tertiary educational institutions.
\end{abstract}

\section{INTRODUCTION}

There is a saying that charity begins at home. A closer look at the family life of some people lends credence to the fact that student or staff act of indiscipline stems very strongly from their homes, and secondly from the environment they found themselves. It is a fact that indiscipline is a problem in most schools nowadays. It could be student or staff or both indiscipline.

Indiscipline in our educational institutions has been the subject of discussion by everyone in the society. In Ebonyi State, every facet of our tertiary educational institution has been dominated by act of indiscipline. Thus, there is indiscipline in everything we do in these tertiary educational institutions (Ebonyi State College of Education, Ikwo and Ebonyi State University, Abakaliki). In these schools, promotions are denied, arrears are not paid, pension/gratuities are not paid, marks are sold, allowances are not paid among others.

Olayinka in Anene (2008) stated that prevalence of disciplinary problems in schools is symptomatic of fundamental deficiencies in the school situation. Ediem in Anene (2008) stated that indiscipline is a violation of school rules and regulation, and is capable of obstructing the smooth and the orderly functioning of the school system, and should be consequently avoided through perfect management of the school by the concerned authorities.

Samuel (2002) stated that indiscipline is non-conformity to the way of the society which would result in the breach of the laws and regulations. In this regard, indiscipline could be seen as a behavior exhibition that runs contrary to uphold school and society values and beliefs.

In a very simple way, Nwobodo (2004) defined indiscipline as lack of discipline. Peretomode (2004) opined that indiscipline could be regarded as any act that does not conform to the societal values and norms. Indiscipline is a destructive and undeserving element to progress, training or mode of life in accordance with rules.

Emma (2007) stated that indiscipline student or staff is recognized by the school. The problem of indiscipline in school has continued to spread like wild fire. Thus, nothing is done in these schools without element of indiscipline.

There is a saying that no smoke without fire. Thus, nothing happens without a cause or reason. In every event, there is give and take; action and reaction. Thus, there must have been some good reasons why there are massive indisciplinary behaviors among the staff of these two tertiary institutions in Ebonyi State. It is the objective of this study to identify the indisciplinary behavoiurs of the staff of these schools; the causes of these indisciplinary behaviours; the effects and the way forward.

\section{STATEMENT OF THE PROBLEM}

There is an out cry in the state of Ebonyi and even beyond that students are exploited financially and materially by the staff of Ebonyi State College of Education Ikwo and Ebonyi State University, Abakaliki. Students of these schools complained of poor attitudes of staff to work, poor teaching, poor results, and extortion among others. The staff on their own complained of gross mismanagement of the school by the school administrators, nonpayment of arrears, non promotion, inadequate provision of both human and material resources, and non-payment 
of retirement benefits among others. Thus, there is break down in every academic activity in these schools, thus every staff is sad.

\section{SIGNIFICANCE OF THE STUDY}

The findings of this study will be beneficial to the government; school management; staff, students and the society at large. The government will benefit because there will be peace and progress in these schools. The good outputs of these schools will form a formidable manpower that will help in the development of this state. The school management will also benefit from the findings if this study as the glory of good performance of these schools will go to them, instead of allowing these schools to collapse in their hands. The staff will equally benefit as the concerned authorities with start paying them all their entitlements and benefits, and they start having their regular promotions. The students on their own will start getting the required and needed skills in the fields of study and there will be no more exploitation in any form. The society will benefit from this study when good and skilled graduates are produced for the society to use. A pool of skilled manpower is an asset to the society instead of producing half baked graduates, cultists and all sorts of animals for the society.

\section{RESEARCH QUESTIONS}

The following research questions guided the study.

(1) What are the natures of staff indiscipline in Ebonyi State owned tertiary educational institutions?

(2) What are the causes of staff indiscipline in Ebonyi State owned tertiary educational institutions?

(3) What are the negative effects of staff indiscipline on the quality of education in Ebonyi State owned tertiary educational institutions?

(4) What strategies could be adopted to curb the problem of staff indiscipline in Ebonyi State owned tertiary educational institutions?

\section{METHODOLOGY}

A descriptive survey design was adopted for the study. The study was carried out in Ebonyi State College of Education Ikwo and Ebonyi State University, Abakaliki among the tutorial and senior non tutorial staff. The population of the study was 2,105 . The sample size for the study was 500 in the ratio of 300 academic staff and 200 non academic staff.

Instrument used for data collection was a structured questionnaire prepared by the researcher. The instrument was made up of two parts, part A and B. Part A sought information on personal data of the respondents, while part B sought information on the four research questions answered using the four (4) point rating scale of: Strongly Agree (SA 4 points), Agree (A 3 points), Disagree (D2 points) and Strongly Disagree (SD1 point).

The instrument was face validated by five experts all from Science Education department of Enugu State University of Science and Technology, Abani.

Test re-test method was used to determine the reliability of the instrument by administering the instrument on ten academic staff and ten non academic staff from Enugu State University of Science and Technology, Abani in two different periods within 21 days. The two results obtained were correlated, using pearson's product moment correlation coefficient which yielded co-efficient index of 0.84 which indicated that the instrument was good.

The researcher with the aid of ten research assistants visited all the administrative offices and lect urers' offices for the distribution and retrieval of the questionnaire instrument. Mean scores were used to answer the research questions while t-test was used to analyze the null hypotheses at 0.05 alpha level of significance. Decision rule: An item stands accepted if it scores a mean of 2.50 and above, while an item with a mean less than 2.50 stands rejected. Likewise for hypotheses, if $\mathrm{t}$-test calculated is less that $\mathrm{t}$-critical value, accept but if $\mathrm{t}$-calculated is greater than $\mathrm{t}$-critical value, reject the hypothesis. 


\section{RESULTS OF DATA ANALYSIS}

Research Question 1: What are the natures of staff indiscipline in Ebonyi State owned tertiary educational institutions?

The data and results generated for this research question one are as presented on table 1 below.

Table 1: Mean results based on responses of respondents on nature of staff indiscipline.

\begin{tabular}{|c|l|l|l|}
\hline S/N & Items & Mean $(\mathbf{X})$ & Decision \\
\hline 1. & Lateness to work & 3.6 & Accepted \\
\hline 2. & Poor teaching/ poor attendance to files & 3.4 & Accepted \\
\hline 3. & Poor attendance to students' problems. & 3.5 & Accepted \\
\hline 4. & Poor attendance to students' projects & 3.3 & Accepted \\
\hline 5. & Poor supervision of teaching practice (T.P)/industrial training (I.T) & 3.7 & Accepted \\
\hline 6. & Poor supervision of examinations & 3.0 & Accepted \\
\hline 7. & Poor conduction of continuous assessment. & 3.8 & Accepted \\
\hline 8. & Poor coverage of course contents & 3.5 & Accepted \\
\hline 9. & $\begin{array}{l}\text { Extortion of money from students either for project supervision, T.P } \\
\text { supervision, I.T or for examination scores; reconciliation of results; } ; \\
\text { result computation, clearance, mobilization for NYSC etc. }\end{array}$ & 3.2 & Accepted \\
\hline 10. & Non availability in office. & 2.6 & \\
\hline 11. & Poor evaluation of students' in examinations. & 2.8 & Accepted \\
\hline 12. & Non or poor marking of students' answer scripts. & 2.7 & Accepted \\
\hline & Grand Mean $(\mathbf{X})$ & $\mathbf{3 . 3}$ & Accepted \\
\hline
\end{tabular}

Data on table one above revealed the nature of indisciplinary behaviors of staff in Ebonyi State owned tertiary educational institutions. It is revealed in table one that all the items, 1-12 scored above the acceptable mean of 2.5. Thus all the listed anti-social behaviours (indiscipline) in table one is obtainable in Ebonyi State owned tertiary educational institutions.

Research Question 2: What are the causes of staff indiscipline in Ebonyi State owned tertiary educational institutions?

The data and results generated for this research question two are as presented on table two below.

Table 2: Mean results based on responses of respondents on causes of staff indiscipline.

\begin{tabular}{|c|l|l|l|}
\hline S/N & Items & Mean (X) & Decision \\
\hline 13. & None promotion of staff & 4.0 & \\
\hline 14. & None payment of promotion arrears & 4.0 & \\
\hline 15. & None payment of office imprest & 3.6 & \\
\hline 16. & None payment of post graduate (PG) supervision & 3.8 & \\
\hline 17. & None payment of PG teaching allowance & 3.0 & \\
\hline 18. & None payment of PG internal examiner allowance. & 3.4 & \\
\hline 19. & None payment of works/study project supervision & 2.7 & \\
\hline 20. & None payment of work and study teaching allowance. & 2.7 & \\
\hline 21. & None payment of academic earned allowance & 4.0 & \\
\hline 22. & None payment of staff retirement benefits via pension and gratuity. & 4.0 & \\
\hline 23. & None payment of death benefit & 4.0 & \\
\hline 24. & None payment of conference attendance & 2.5 & 3.0 \\
\hline 25. & High taxation on staff salaries & 2.8 & \\
\hline 26. & Non recognition of outstanding performance. & 3.0 & \\
\hline 27. & Admission of very weak students using quota system. & 2.7 & \\
\hline 28. & Employment of staff without due process, thus employing quacks. & 2.6 & \\
\hline 29. & Not using due process in all cases & 2.8 & $\mathbf{3 . 3}$ \\
\hline 30. & Poor teaching/office materials. & Grand Mean (X) & \\
\hline & Dat on tablwo above revealed the causes of & \\
\hline
\end{tabular}

Data on table two above revealed the causes of staff indisciplinary behaviors of staff in Ebonyi State owned tertiary educational institutions. All the items, 13-30 scored above the acceptable mean of 2.5, thus all the items were accepted as the real causes of indiscipline among the staff of Ebonyi State tertiary educational institutions. 
Research Question 3: What are the negative effects of staff indiscipline on the quality of education in Ebonyi State owned tertiary educational institutions?

The data and results generated for this research question three are as presented on table three below.

Table 3: Mean results based on responses of respondents on the negative effects of staff indiscipline on the quality of education in Ebonyi State owned tertiary educational institutions.

\begin{tabular}{|c|l|l|l|}
\hline S/N & Items & Mean $(\mathbf{X})$ & Decision \\
\hline 31. & Production of unemployable graduates & 3.0 & \\
\hline 32. & Awarding unmerited marks to students & 3.2 & \\
\hline 33. & Production of half baked graduates. & 3.5 & \\
\hline 34. & Denying students the needed skills & 3.6 & \\
\hline 35. & Teaching the students how to be corrupt & 3.5 & \\
\hline 36. & Destroying the image of the school & 3.7 & \\
\hline & Grand Mean $(\mathbf{X})$ & $\mathbf{3 . 4}$ & \\
\hline
\end{tabular}

Data and results generated from table three above revealed the negative effects of indisciplinary behaviors of staff on the students. It is revealed that all the items on table three are negative effects of indiscipline among staff as they all (31-36) scored above the acceptable mean of 2.5 .

Research Question 4: What strategies could be adopted to curb the problem of staff indiscipline in Ebonyi State owned tertiary educational institutions?

The data and results generated for this research question four are as presented on table four below.

Table 4: Mean results based on responses of respondents on strategies to be adopted to curb the problem of indiscipline in Ebonyi State owned tertiary educational institutions.

\begin{tabular}{|c|l|l|l|}
\hline S/N & Items & Mean (X) & Decision \\
\hline 37. & Regular promotion of staff. & 4.0 & \\
\hline 38. & Regular office imprest & 3.5 & \\
\hline 39. & Regular payment of PG Allowances & 3.5 & \\
\hline 40. & Regular payment of work/study allowances & 3.0 & \\
\hline 41. & Immediate payment of all staff arrears & 4.0 & \\
\hline 42. & Provision of adequate staff & 2.8 & \\
\hline 43. & Provision of adequate material resources & 2.6 & \\
\hline 44. & Admission to be based on academic performance & 3.1 & \\
\hline 45. & Payment of staff retirement benefits & 4.0 & \\
\hline 46. & Payment of staff death benefits & 4.0 & \\
\hline 47. & Follow due process in staff recruitment & 2.6 & \\
\hline 48. & Follow due process in staff discipline & 2.8 & \\
\hline 49. & Encourage staff development programme & 3.2 & \\
\hline 50. & Annual award of honours to outstanding performing staff & 3.5 & \\
\hline & Grand Mean $(\mathbf{X})$ & $\mathbf{3 . 3}$ & \\
\hline
\end{tabular}

Data and results generated from table four above revealed strategies to be adopted by the school management to solve the problem of indiscipline among the staff. All the suggested strategies were all accepted by the respondents as the panacea to the problem of indiscipline among staff of Ebonyi State owned tertiary educational institutions as none of them scored a mean less than 2.5 which is the acceptable mean.

\section{TEST OF HYPOTHESES}

Hypothesis One: There is no significant difference in the mean ratings of academic staff and no academic staff on the nature of indiscipline among staff in tertiary educational institutions owned by Ebonyi State government. Data collected from the respondents for this study were separated across the two staff categories of academic and nonacademic staff.

Table 5: T-test result on the nature of indiscipline among staff in tertiary educational institution owned by Ebonyi State government.

\begin{tabular}{|l|l|l|l|l|l|l|l|}
\hline Variables & No. & $\overline{\mathbf{X}}$ & Df & t-cal & t-cri & Decision & Significance \\
\hline Academic staff & 300 & 3.4 & & 0.84 & 1.96 & Upheld & Not significant \\
\hline Non-Academic staff & 200 & 3.3 & & & & $\mathrm{HO}_{1}$ & \\
\hline
\end{tabular}


Results in table five showed that t-test calculated value of 0.84 is less than t-critical value of 1.96 . Hence, the null hypothesis $\left(\mathrm{HO}_{1}\right)$ is upheld as true. Meaning that there is no significant difference in the mean ratings of academic staff and non-academic staff on the nature of indiscipline among staff in tertiary educational institutions in Ebonyi State.

Hypothesis Two: There is no significant difference in the mean ratings of academic staff and non academic staff on the causes of indiscipline in Ebonyi State owned tertiary educational institutions.

Data collected from the respondents for this study were separated across the two staff categories of academic and nonacademic staff.

Table 6: T-test result on the causes of indiscipline in Ebonyi State owned tertiary educational institutions.

\begin{tabular}{|l|l|l|l|l|l|l|l|}
\hline Variables & No. & $\overline{\mathbf{X}}$ & Df & t-cal & t-cri & Decision & Significance \\
\hline Academic staff & 300 & 3.5 & 498 & 0.94 & 1.96 & Upheld & Not significant \\
\hline Non-Academic staff & 200 & 3.3 & & & & $\mathrm{HO}_{2}$ & \\
\hline
\end{tabular}

Results in table six showed that t-calculated value of 0.94 is less than t-critical value of 1.96 . Hence, the null hypothesis $\left(\mathrm{HO}_{2}\right)$ is upheld. Meaning that there is no significant difference in the mean ratings of academic staff and nonacademic staff on the causes of indiscipline among staff in tertiary educational institutions owned by Ebonyi State government.

Hypothesis Three: There is no significant difference in the mean ratings of academic staff and non academic staff on the strategies to be adopted to solve the problem of indiscipline among staff of tertiary educational institutions owned by Ebonyi State government.

Data collected from the respondents for this study were separated across the two staff categories of academic and nonacademic staff.

Table 7: T-test result on the strategies to be adopted to solve the problem of indiscipline among staff of tertiary educational institutions owned by Ebonyi State government.

\begin{tabular}{|l|l|l|l|l|l|l|l|}
\hline Variables & No. & $\mathbf{X}$ & Df & t-cal & t-cri & Decision & Significance \\
\hline Academic staff & 300 & 3.6 & 498 & 0.84 & 1.96 & Upheld & Not significant \\
\hline Non-Academic staff & 200 & 3.5 & & & & $\mathrm{HO}_{3}$ & \\
\hline
\end{tabular}

Results in table seven showed that $t$-calculated value of 0.84 is less than $t$-critical value of 1.96 . Hence, the null hypothesis $\left(\mathrm{HO}_{3}\right)$ is upheld. Meaning that there is no significant difference in the mean ratings of academic staff and nonacademic staff strategies to be adopted to curb indiscipline among staff of tertiary educational institutions owned by Ebonyi State government.

\section{SUMMARY OF FINDINGS}

The study found among others the nature of indiscipline among staff Ebonyi State owned tertiary educational institutions to include:

(1) Lateness to work.

(2) Poor teaching.

(3) Extortion of money from students etc.

\section{Causes of Indiscipline:}

(1) None promotion of staff.

(2) None payment of retirement benefits

(3) None payment of earned allowances.

(4) None payment of promotion arrears etc.

\section{Negative Effects of Indiscipline on Quality of Education:}

(1) Production of half baked graduates.

(2) Denying students of needed skills etc.

Strategies to be Adopted to Curb the Problem of Indiscipline Among Staff:

(1) Regular promotion of staff.

(2) Regular payment of PG allowances.

(3) Payment of earned allowance,

(4) Payment of retirement benefits etc. 


\section{DISCUSSION OF FINDINGS}

The study sought to identify the nature of staff indiscipline in tertiary educational institutions in Ebonyi State. The results as seen in table 1 revealed the nature of indiscipline to include: lateness; poor teaching, poor attendance to students' problems etc. The above findings are in line with Okeke (2015) who opined that lateness, absenteeism, poor teaching and collection of illegal levies abound in our educational institutions.

The study in table two revealed many causes of staff indiscipline to include; non promotion, non-payment of arrears, non-payment of retirement benefits. These findings are in line with Nze (2016) who opined that many industrial actions in Nigeria were caused by non-payment of arrears and retirement benefits. Nweke (2017) revealed that the major reason for the falling standard in education in Nigeria is found in the poor attitude of teachers towards teaching and learning caused by poor treatment meted out for teachers by their employer. Nweke (2017) revelation above is in agreement with the findings of this study where teachers got to work late, do not teach well, do not cover their scheme of work, do not invigilate examinations very well, do not pay serious attention to students' problems among others. The end of discussion is that the study has identified the nature, causes, effects of indiscipline and strategies to be used to address the situation. The only thing left is to implement the findings/results of the study.

\section{CONCLUSION}

Based on the results of this study, the researcher concluded that lateness, poor teaching among others constitute the nature of indiscipline, while lack of promotion, non-payment arrears, retirement benefits, earned allowance etc constitute causes of indiscipline. The study $x$-rayed also negative effects of indiscipline on the quality of education and suggested strategies the issue of indiscipline among staff of tertiary educational institutions owned by Ebonyi State government.

\section{RECOMMENDATIONS}

Based on the findings of the study, the following recommendations were made:

(1) That are the suggested and accepted strategies as are contained in table four should be put into use immediately, as this will serve as panacea to the problem of indiscipline in Ebonyi State owned tertiary educational institutions.

\section{REFERENCES}

- Anene U. (2008) Discipline in school. Benin: Hallmark Publishers.

- Samuel, S. (2002) Citizenship of education in Nigeria. Asaba: Standard Press bookshop.

- Peretomode, V. F. (2004). Introduction to educational administration and supervision in Nigeria. Ibadan: Spectrumbook Ltd.

- Nwobodo, P. U (2004). Citizenship of Education Nsukka: Prize Publishers Ltd.

- Emma, T. O. (2007). Issues in school discipline. Calabar: Udenze Press Ltd.

- Nweke, O. O. (2017). Causes of indiscipline in Schools. Aba: T-shape Book Publishers.

- Nze, J. O. (2016). Evils of indiscipline in our educational systems. Onitsha: 4-square educational publications.

- Okeke, N. J. (2015) Indiscipline Vs Quality of education. Asaba: ABC Book Publishers. 